Fakultas Hukum, Universitas Lampung, Bandar Lampung, Lampung, Indonesia. http://jurnal.fh.unila.ac.id/index.php/corruptio

Volume 01 Issue 1, January - June 2020. PP: 49-62

P-ISSN: 2723-2573

E-ISSN: 2745-9276

\title{
Changes in Corruption Eradication Commission In Legal Sociology Perspective
}

\author{
Joko Sriwidodo \\ jokosriwidodo@gmail.com \& joko_sriwidodo@jayabaya.ac.id \\ Permanent Lecturer in Postgraduate Masters in Law Jayabaya University Jakarta
}

Submitted: Mar 9, 2020; Reviewed: Mar 26, 2020; Accepted: Apr 24, 2020

\begin{tabular}{|c|c|}
\hline Article Info & Abstract \\
\hline $\begin{array}{l}\text { Keywords: Law; Corruption Eradication } \\
\text { Commission; and Sociology of Law. } \\
\text { DOI: } \\
\text { https://doi.org/10.25041/corruptio.v1i1.2073 }\end{array}$ & $\begin{array}{l}\text { The Corruption Eradication } \\
\text { Commission is an independent } \\
\text { state institution whose job it is to } \\
\text { carry out the duties and powers of } \\
\text { corruption eradication free from } \\
\text { any power. The Corruption } \\
\text { Eradication Commission was born } \\
\text { during the reign of President } \\
\text { Megawati, namely through Law } \\
\text { No. } 30 \text { of } 2002 \text { concerning the } \\
\text { Corruption Eradication } \\
\text { Commission. In } 2019 \text { there was a } \\
\text { revision of the Corruption } \\
\text { Eradication Commission Law, but } \\
\text { the revision was opposed by the } \\
\text { public, because the change was } \\
\text { seen as likely to weaken the } \\
\text { Corruption Eradication } \\
\text { Commission. Observing the brief } \\
\text { description above, the researcher } \\
\text { in this paper wants to raise at least } \\
2 \text { problems, namely; 1), Are the } \\
\text { three foundations for the } \\
\text { formation and amendment of the } \\
\text { Prevailing Laws, namely juridical, } \\
\text { philosophical and sociological } \\
\text { elements that have been fulfilled }\end{array}$ \\
\hline
\end{tabular}


in the amendment of the Corruption Eradication Commission Law? 2), is the amendment to the Corruption Eradication Commission Law in accordance with the expectations and realities in society from the perspective of legal sociology? This paper would like to try to provide an overview of the Corruption Eradication Commision and the Amendment to the Corruption Eradication Commision Law, both in the prevailing legal normative theory and in current practice. This research is a normative legal research which is carried out through library research. The discussion in the research, if viewed from the aspect of fulfilling the foundation for the formation and changes of laws and regulations, then the amendments to the Corruption Eradication Commision have fulfilled these aspects, namely philosophical, sociological and juridical aspects in which the Corruption Eradication Commision itself has existed for 17 years in carry out its duties and authorities as an agency to eradicate corruption. Meanwhile, from the perspective of legal sociology, the public does not want any changes to the Corruption Eradication Commision, in which the Corruption Eradication Commision is still the institution of public trust in eradicating corruption in Indonesia. 


\section{A. Preliminary}

Soerjono Soekanto, an expert in Indonesian legal sociology, once stated that law enforcement does not mean merely the implementation of legislation, although in reality in Indonesia the tendency is like that. Meanwhile, Lawrence M. Friedman gave an answer whether the success or failure of law enforcement depends on the legal substance, legal structure, and legal culture. ${ }^{1}$

We also need to remember that in the structure of legal life in Indonesia there is a strong tendency to interpret law enforcement as the implementation of judges' decisions. This opinion also needs to have weaknesses, even though the judge's decision is a binding decision. However, if the implementation of the law or the judge's decision disturbs peace in one's life, it is also necessary to conduct a review.

In connection with the law enforcement process (law enforcement), particularly law enforcement on corruption. The various efforts to eradicate corruption that have been carried out by the Indonesian government have not been fully effective and have yielded satisfactory results.

With so many regulations governing the crime of corruption, it turns out that it does not guarantee a reduction in corruption cases in this country. Even tragically the Anti-Rasuah Institute or what we know as the Corruption Eradication Commission, which is one of the institutions that has the main task of eradicating corruption, seems to be rendered powerless to face pressure from several parties. Therefore a good law is of course useless if it is not enforced, this is in line with the existence of regulations.

Viewed from the perspective of legal sociology, the inconsistent and non-transparent law enforcement process ultimately affects the level of public trust in the law and its officials. This then triggers the public assumption that the law can no longer be trusted as a means of resolving conflicts, furthermore, it is not impossible for other parties to take advantage of the inconsistency of law enforcers for the benefit of themselves and their groups.

If we look back at the mandate of a reform agenda, then one of the agendas is legal reform, which at that time felt important and very urgent to be implemented, was reform in law enforcement. Furthermore, if we relate it to the scope of law enforcement against corruption, it does not need to be emphasized again that corruption is the main problem of our nation, because corruption is the source of the failure of a nation's development. Although there are still many problems in other nations, corruption is the root of the problem. Thus, the assumption of our freedom being seized by corruptors is correct. This country has become independent, but the effects of development have not been felt by many citizens of the nation, due to rampant corruption.

In the era of President Joko Widodo's administration, the discourse on changing the law of the Corruption Eradication Commision was listed again as one of the 2016 prolegnas plan lists. In this case Prof. Saldi Isra provides an in-depth analysis of the revision of Law No. 30/2002, which consists of four revisions: (1) the desire to establish a supervisory board for the Corruption Eradication Commision; (2) Tapping and confiscation requiring permission from the supervisory board; (3) authorizing the Corruption Eradication Commision to issue an order to stop investigation; and (4) the appointment of independent investigators. ${ }^{2}$

It can be clearly stated that some of these substances have undermined the authority of the Corruption Eradication Commision in eradicating corruption and of course have an impact

\footnotetext{
1.Adam Setiawan, Balada KPK Dalam Perspektif Sosiologi Hukum, dalam https://www.google.com/amp/s/kastara.id/14/02/2019/balada-kpk-dalam-perspektif-sosiologi-hukum/amp/ diakses tanggal 17 Desember 2019

${ }^{2}$ Ibid.
} 
on its ineffectiveness in eradicating corruption. In addition, the challenges faced by the Corruption Eradication Commision are efforts to weaken the Corruption Eradication Commision which culminates in in 2017.

The House of Representatives as an institution that has a direct mandate from the people, should fully support the law enforcement process carried out by the Corruption Eradication Commision in eradicating corruption. The House of Representatives has even become the most corrupt institution due to the actions of several individuals who have abused their position (abuse of power).

If viewed from a statutory point of view, the effectiveness of legislation in achieving its objectives may have side effects. so it is necessary to distinguish between a policy orientation and a sociological orientation. These differences are as follows: ${ }^{3}$

1. Policy Orientation:

a. The effectiveness of legislation in terms of its own objectives or its effects

b. Unexpected consequences of legislation beyond the foreseeable purpose

2. Sociological Orientation:

a. Values and their relationship with legislation include the study of statutory ideology, public opinion and legal awareness.

b. Interests and their relationship with legislation, including studies of pressure group activities and the workings of legislators.

Colombotos requires a statutory regulation to be considered effective if it meets the following elements ${ }^{4}$;

1. There is a level of legal compatibility between the existing values:Possible implementation of the law:

2. Purity of government policies and persistence in law enforcement.

According to Soerjono Soekanto, a newly introduced rule or rule must go through a process of institutionalization, which is a process that must be passed by a new principle to be recognized, recognized, appreciated and obeyed by the community. ${ }^{5}$

If viewed from the perspective of legal sociology, the Corruption Eradication Commission was established based on Law no. 30 of 2002, is one of the biological children of reform as the demand for the establishment of this institution arose due to public anxiety about the weak performance of 3 (three) law enforcers in Indonesia, namely the Police, Prosecutors and Judges in handling and eradicating increasingly rampant corruption. They seem to be not functioning in this case, it is as if the corruptors are not being treated properly, even as if they are even turned into a gold mine by law enforcers.

\section{B. Formulation Of The Problem}

1. Have the three foundations for the formation and amendment of the Prevailing Laws, namely juridical, philosophical and sociological elements been fulfilled in the amendment of the Law on the Eradication of Corruption Eradication Commission?

2. Is the Amendment of the Corruption Eradication Commission Law in accordance with the expectations and realities in society from the perspective of legal sociology?

\section{Research Methods}

\footnotetext{
${ }^{3}$ Jufrina Rizal, Sosiologi Perundang-Undangan dan Pemanfaatannya, Jurnal Hukum dan Pembangunan, Nomor 3 Tahun XXXIII. hlm.422

${ }^{4}$ Tomasic. R, "The Sociology Legislation", dalam Legislation and Society in Australia, The Law Foundation of New South Wales and George Allen and Unwin, Sidney, Australia, 1979, hlm.35-37

${ }^{5}$ Soerjono Soekanto, Sosiologi Suatu Pengantar, (Jakarta, PT. Raja Grafindo Persada, 1990). hlm. 373
} 
This research is normative law research using normative case studies in the form of legal behavior products, for example reviewing laws. The main point of the study is the law conceptualized as norms or rules that apply in society and become a reference for everyone's behavior. So that normative legal research focuses on the inventory of positive law, legal principles and doctrines, legal findings in inconcreto cases, legal systematic, level of synchronization, comparative law and legal history. ${ }^{6}$

Based on the explanation above, the authors decided to use normative legal research methods to research and write a discussion of this research as a legal research method. The use of normative research methods in this research and writing effort is based on the suitability of the theory and the research method required by the author.

The approach method in this research is the statutory approach. ${ }^{7}$ A normative research certainly has to use a statutory approach, because what will be examined are various legal rules that become the focus as well as the central theme of a study. Meanwhile, the data analysis carried out in this study was carried out with a more qualitative approach, namely to reveal as much data (legal material) as possible so that the issues raised were more transparent. The qualitative approach allows the researcher to elaborate the data obtained in a comprehensive manner and the results of the description are more accountable.

\section{Theoretical Framework}

Theory is a guide in determining the objectives and direction of research. ${ }^{8}$ To analyze the data collected in order to answer the above questions, this study uses the sociology of law theory, especially the theory proposed by Brade Meyer regarding the Sociology of the law, namely making law a central tool for sociological research, which is the same as how sociology studies a another small group. The use of this theory is to analyze the relationship between a legal product and social symptoms. As well as the definition of the sociology of law, which is a science that studies the interrelationship between law and other social phenomena in an analytical way. ${ }^{9}$

This research also uses the theory of legal certainty a little. The issue of legal certainty in relation to the implementation of the law cannot be completely separated from human behavior. Legal certainty does not follow the principle of "push the button" (automatic subsumption), but something that is quite complicated, which has a lot to do with factors outside the law itself. Talking about certainty, then as said by Radbruch, what is more precise is the certainty of the existence of the regulation itself or the certainty of the rules (sicherkeitdes Rechts). ${ }^{10}$ Legal certainty requires efforts to regulate law in legislation made by an authorized and authoritative party, so that the rules have a juridical aspect that can guarantee certainty that the law functions as a regulation that must be obeyed.

The use of sociological theory of law and legal certainty is to see the public's response to the amendments to the Corruption Eradication Commission Law.

\section{E. Conceptual Framework}

\section{Corruption Eradictional Commision}

The Corruption Eradication Commission was founded in 2002 and was founded by President Megawati Soekarnoputri. As for the formation of the Corruption Eradication

\footnotetext{
${ }^{6}$ Abdul kadir Muhammad. Hukum dan Penelitian Hukum.Cet. 1. (Bandung: PT. Citra Aditya Bakti. 2004). hlm.52

${ }^{7}$ Peter Mahmud Marzuki, Penelitian Hukum. Cet2. (Jakarta: Kencana. 2008). hlm.29

${ }^{8}$ Sri Mamudji, Hang Rahardjo, dkk., Metode Penelitian dan Penulisan Hukum, (Jakarta, Badan Penerbit Fakultas Hukum Universitas Indonesia, 2005), hlm.18-19

9 Joko Sriwidodo, Hukum Dalam Perspektif Sosiologi dan Politik di Indonesia", (Yogyakarta, Kepel Press, 2020), hlm.4

${ }^{10}$ Satjipto Rahardjo, Hukum Dalam Jagat. Op.Cit. hlm.139
} 
Commission, it was based on the fact that the President of the Republic of Indonesia at that time saw that the police and prosecutors were considered too dirty, and therefore it was felt that he was unable to arrest corruptors. In addition, it was difficult for the police and prosecutors to be disbanded so that the Corruption Eradication Commission was formed. The establishment of the Corruption Eradication Commission is stipulated in Law No. 30 of 2002 regarding the Corruption Eradication Commission

Corruption Eradication is an independent state institution that in carrying out its duties and authorities is free from any power. The head of the corruption eradication commission consists of five people who also serve as members, all of whom are state officials. The leadership consists of elements from the community and elements of the government, so that the system of supervision carried out by the community on the performance of the Corruption Eradication Commission in carrying out investigations, investigations and prosecutions of perpetrators of criminal acts of corruption remains attached to the Corruption Eradication Commission.

Apart from being transparent and involving public participation, the requirements to become a member of the Corruption Eradication Commission must also meet administrative requirements and must go through a due diligence conducted by the DPR (People's Representative Council), which is then confirmed by the president of the Republic of Indonesia.

In carrying out the duties and powers of the Corruption Eradication Commission, namely investigations, investigations and prosecutions, the Corruption Eradication Commission also follows the procedural law stipulated in the prevailing laws and regulations and Law No. 20 of 2001 regarding the eradication of criminal acts of corruption. This law contains a separate procedural law as a special provision. To improve the efficiency and effectiveness of law enforcement against corruption, this Law regulates the establishment of a corruption court in the general court, namely in the Central Jakarta District Court for the first time. The corruption court has the duty and authority to examine and decide cases of corruption committed by a judicial panel consisting of two district court judges and three ad hoc judges, this also applies to the examination process at both the appeal and cassation level.

Seeing the enormous authority of the Corruption Eradication Commission and its independent position, the hope of the Indonesian people only remains with the Corruption Eradication Commission to be able to enforce laws and regulations in the field of corruption, because conventional institutions such as auditors, police and prosecutors are deemed incapable. Law enforcement to eradicate criminal acts of corruption committed by auditors, police and prosecutors has so far been proven to experience various obstacles, because these auditors and law enforcers participated in corruption.

\section{Sociology Of Law}

Law is a social institution whose aim is to deliver justice in society. As a social institution, its implementation is related to the level of ability of the community itself to carry it out. Therefore, a society will carry it out in a certain way that is different from society in other societies. This difference is closely related to the supply of equipment that is in society for the administration of justice and this right means that there is a close relationship between the legal institutions of a society and the level of development of its social organization.

An observation of society sociologically shows that power is not evenly distributed in society. Such a distribution structure causes that power is accumulated in a certain group of people, while other people do not or lack that power. This kind of situation has created a social stratification in society. How this multi-layered structure can be formed depends a lot on the economic system of a society. The accumulation of power in the hands of a certain 
group of people is related to the system of sharing resources in society. Power is inseparable from the control of goods in society.

Therefore, the occurrence of a layer of power is closely related to the goods that can be distributed. It is certainly difficult to imagine the emergence of a social stratification in society. The condition of the procurement of goods determines whether a society will find a multi-layered power structure. The importance of discussions on social strata in the context of discussions on law is due to the impact of such a structure on law, both in the field of lawmaking, implementation and settlement of disputes. In any society, people or groups who can exercise their power effectively are those who are able to control political and economic institutions in society.

The sociologists of law pay great attention to the relationship between law and this social strata. With the occurrence of social stratification, it is difficult for the law to pay attention to its neutrality or impartial position. This social strata is the key to explaining why the law is discriminatory, both in its own regulations and through its enforcement. These experts argued in advance that the legal regulations were not impartial. In such a situation the ruling opinion will determine how the content of the legal regulations there.

Thus, after all efforts are made to ensure that law enforcement is impartial, but because since the birth of these regulations they are not legal, the law is also impartial, such a situation is also found in matters of law enforcement. If we now know how big the role of law is in helping to create order and smoothness in people's lives, we still don't really know what the law intends.

When we say that the laws are intended to create order, we are really only dealing with matters of a technical nature. Prohibiting people from committing theft by creating a law with the penalty is a technical effort. But why is stealing what is forbidden? The answer is, because stealing is considered a disgraceful act by society. Thus, we have entered into a field that is no longer technical in nature, but is ideal.

This discussion is expected to provide insight that is more in line with the reality in our review and study of law, namely that law is present in society because it has to serve certain needs and must process certain materials that it must accept as a fact. Since the law provides such limitations, the legal institution can only operate properly in a social and political environment which can be effectively controlled by law. A society that wishes to be governed by law but which is not willing to allow the use of its power to be limited and controlled is not a good environment for the development of legal institutions.

Law as Social Control, where every group of society always has problems as a result of the difference between the ideal and the actual, between the standard and the practical. Deviations of ideal values in society can be exemplified: corruption, theft, adultery, debt, murder and others. All of these examples are forms of deviant behavior that cause problems in society, both in simple and modern societies. In such a situation, the group is faced with the problem of ensuring order if the group wants to maintain its existence.

The function of law in community groups is to implement a social control mechanism that will rid society of unwanted community waste, so that the law has a function to maintain the existence of that community group. The law that functions in this way is an instrument of social control.

Law as a tool to change society, is law as a social control, and as a tool for changing society or so-called socialenginnering, as a means of changing society is analogous to a mechanical process. It can be seen that the result of industrial development and business transactions that introduce new values, by making "interpretations", is confirmed by findings about the social condition of society through the help of sociology, it will be seen that there 
are values or norms about individual rights. which must be protected, and these elements are then held by the community in maintaining what is known as natural law.

Therefore, even though the law has a certain autonomy, the law must also be functional and place the role of justice in the context of legal life more carefully.

\section{Discussion}

\section{a. Fulfillment of Philosophical, Sociological and Juridical Foundations in the Amendment of the Corruption Eradication Commission Law}

As we know, that in every formation of laws and regulations or amendments to laws, three foundations must be fulfilled, namely the philosophical, sociological and juridical foundations.

Philosophical Basis (Filosofische grondslag), the philosophy or way of life of a nation that contains moral or ethical values of the nation. Morals and ethics are basically good values and bad values. Good values are views and ideals that are upheld that contain the values of truth, justice, decency, and various other values that are considered good. The meaning of good, correct, fair, and moral is according to the measurements held by the nation concerned. Good laws must be based on them. Laws that are formed without paying attention to the morals of the nation will be in vain and will not be obeyed or obeyed.

Sociological Basis (Sosiologische grondslag). A statutory regulation is said to have a sociological basis if its provisions are in accordance with the general belief or legal awareness of the community. This is important so that the laws that are made will be obeyed by the community, not become mere letters.

Juridical basis (Juridische grondslag), juridical basis is a legal basis (juridische gelding) which forms the basis of authority (bevoegdheid competentie) in the making of legislation. Does the authority of an official or entity have a legal basis as stipulated in statutory regulations or not. The legal basis for the authority to form laws and regulations is needed.

The three bases above, must be fulfilled in every formation or change of laws and regulations. Likewise, what happened to the amendment to the Corruption Eradication Commission Law, where all three bases have been fulfilled.

As stated by Prof. Romli Atmasasmita, a criminal law expert who is also the head of the drafting law, the establishment of the Corruption Eradication Commission. Romli Atmasasmita assessed that the amendment to Law Number 30 of 2002 concerning the Corruption Eradication Commission had gone through philosophical, juridical and sociological considerations. First, the philosophical consideration is that the Corruption Eradication Commission's journey for 17 years has deviated from its original objective. According to Romli, the anti-graft agency should maintain and maintain a balance in the implementation of prevention and prosecution with the aim of maximizing state loss. The Corruption Eradication Commission should also carry out a trigger mechanism function through coordination and supervision of the police and prosecutors. Second, sociological considerations, Romli said that public support for the Corruption Eradication Commission remains stable although not at all levels of the bureaucracy and levels of society. Third, the juridical aspect, Romli said, it can be seen from the Constitutional Court's decision regarding the judicial review of the Corruption Eradication Commission Law. In this decision, it was stated that the Corruption Eradication Commission was an independent branch of the executive power that deals with corruption issues. From this juridical consideration, Romli also said that the proposed amendments to the Corruption Eradication Commission Law had met the requirements of Law Number 12 of 2011 concerning the Establishment of Legislation. Romli also touched on the violation of procedural law procedures and the standard procedures of the Corruption Eradication Commission in investigations and 
investigations. This is particularly true in terms of determining suspects, seizing the assets of the defendants, and carrying out wiretapping followed by arrests.

In line with what Prof. Romli said above, that the philosophical, sociological and juridical foundations that are normative in a statutory regulation have been fulfilled considering that the Corruption Eradication Commission has existed for 17 years in carrying out its duties as an agency to eradicate corruption.

\section{b. Sociological Review in Amendments to the Corruption Eradication Commission Law}

Sociology of Law, especially sociology of legislation or sociology of lawmaking, can help provide clarity about the existing capabilities of legislation and the effects it causes in society. According to the sociologist from Poland Podgorecki. many limitations arise due to the reluctance of legislators to consult social scientists. A good law should be based on practical studies carried out by social scientists and legal sociologists in particular. ${ }^{11}$

Basically, the anticipation from the sociologist of legislation can help the work of making laws, for example by looking at the dynamic changes in legislation. the relationship between group interests and legislation, statutory relationship with values, ideology and so on. Sociologically, as also stated by Satjipto Rahardjo, lawmaking cannot be seen as a sterile and absolutely autonomous activity. In this perspective, lawmaking has social origins, social goals, experiences social intervention and also has social impacts.

As was also stated by Jeremy Bentham "the great happiness for the great numbers" as a goal that must be realized in the making of laws in order to realize "the true good of the community." ${ }^{2}$. Bentham's study, according to Satjipto Rahardjo, regarding lawmaking has gone from technical legislation to discussion within the broader framework of social life, the measurements and formats used are not merely rationality, procedural logic but sociological entries. $^{13}$, where the inside is ${ }^{14}$ :

1) the social origin of the Law;

2) reveal the motives behind the making of laws;

3) see the making of laws as a deposit of conflicts of strength and interests of the people:

4) the structure of the legislature and its sociological implications:

5) discusses the relationship between the quality and number of laws made and the social environment in a certain period:

6) target behavior to be regulated and changed;

7) consequences, whether intended or not.

A French scholar, Carbonnier sociological lawmaking can be categorized into two things: first, related to the legislative mechanism is an aspect that is independent of what legislators produce, in this case categorized in sociologie legislative externe; second, the application related to the content of the law, which is categorized in a process known as "sociologie legislative interne". ${ }^{15}$

\footnotetext{
${ }^{11}$ Tomasic, R, "The Sociology Legislation" dalam Legislation and Society in Australia, The Law Foundation of New South Wales and George Allen and Unwin, Sidney, Australia. 1979, hlm. 32.

12 Jeremy Bentham. Theory of Legislation. London, Trubner \& Co. 1979. Lihat juga dalam Jufrina Rizal, Sosiologi Perundang-Undangan dan Pemanfaatannya, Jurnal Hukum dan Pembangunan, Nomor 3 Tahun XXXIII. hlm.418

13 Satjipto Rahardjo dalam "Sosiologi Hukum; Perkembangan, Metode dan Pilihan Masalahnya" (editor Khudzaifah Dimyati), (Surakarta, Universitas Muhammadiah Surakarta. 2002).

${ }_{14}$ Jufrina Rizal, Sosiologi Perundang-Undangan dan Pemanfaatannya, Jurnal Hukum dan Pembangunan, Nomor 3 Tahun XXXIII. hlm.418-419

${ }^{15}$ Jean Carbonnier. Sociologie Juridique. (Paris. Presses Universitaires de France. 1978), hlm. 393.
} 
In the sense of sociology legislative externe, law-making can only be done with the help of persons or institutions outside the legislators. The government as the party having the responsibility decides to make the necessary regulations. In this regard, sociology can be applied to pave the way for the desired changes, namely through the process of preparing the law, which is known as an antelegislative sociologie (Pre-Legislation). As for the process after the enactment of the law, known as a postlegislative sociologie (post-legislative or can be called post-legislation), we can see whether the law can work well or not. In this case Carbonnier likens the legislature as a "company", which requires public relations services to deal with users of the law or consumers of a product - in this case as consumers of the law. ${ }^{16}$

According to Carbonnier, in the process of preparation or pre-legislation, basically sociologists can be asked for assistance in obtaining the necessary inputs, opinions or opinions not only from parliament but also from the public as "consumers". The hypothesis put forward is that these opinions often do not want reform, as happened in the planned amendment to the Corruption Eradication Commission Law which is currently happening in Indonesia, where there is massive resistance from the public to the amendments to the Corruption Eradication Commission Law, where The public believes that changes to the Corruption Eradication Commission Law are not changes to strengthening the Corruption Eradication Commission, but changes to weaken the Corruption Eradication Commission.

The role of social scientists in providing input to the legislature cannot be said that legislators are dictated by sociologists. Even in countries which have opened themselves up to a sociological approach, legislators are still responsible for lawmaking. Sociologists can collaborate with the legislative or executive institutions with their respective roles and functions, meaning that the task of making laws does not shift to his shoulders, because he only provides valuable input for consideration.

The legislature can request research to be carried out, either based on methods in sociology or methods from other disciplines. The problem that often arises is that highly dogmatic jurists tend to reject it. Usually the arguments used are philosophical arguments. However, empirical arguments will be able to negate or at least reduce the very tense debate in parliament. The role of the Sociology of Law in making laws is not only to solve the problem of acceptance of a reform, but also plays a role as soon as the law is promulgated. Sociological analysis through the results of a widely distributed questionnaire can capture social phenomena that are ignored by law.

In addition, sociologists can also assist the government in disseminating information dissemination through mass media, both print and electronic media, to complement formal publications from the government which are often ineffective. This questionnaire and publication can be made periodically for evaluation material for the government. Essentially. A good statutory regulation is not enough if it only meets philosophical and juridical requirements. but sociologically these rules apply. Juridically, it means that it is in accordance with the applicable legal rules and is made by the competent institution, while philosophically it does not contradict the essential values in society and ultimately sociologically, these regulations are in accordance with the realities that live in society.

Based on the sociological basis that we have mentioned in the first sub-discussion above, the sociological reasons for the amendment to the Corruption Eradication Commission Law $\operatorname{are}^{17}$ :

Whereas government agencies that handle corruption cases have not functioned effectively and efficiently in eradicating corruption crimes.

\footnotetext{
${ }^{16}$ Jufrina Rizal, Sosiologi Perundang-Undangan ....Op cit... hlm.419

17 Prof. Dr. Indriyanto Seno Adji, dkk., Pengujian oleh Publik (Public Review) Terhadap Rancangan Undang-Undang Tentang Komisi Pemberantasan Tindak Pidana Korupsi, (Jakarta, Indonesia Corruption Watch, 2016). hlm. 13
} 
That the implementation of the duties of the Corruption Eradication Commission needs to be improved through a comprehensive strategy to eradicate corruption in accordance with the provisions of laws and regulations.

Responding to changes to the Corruption Eradication Commission Law, the public and also almost all Corruption Eradication Commission employees rejected that there were at least 26 problems in the revision of the Corruption Eradication Commission Law, as summarized by the Corruption Eradication Commission itself, namely; ${ }^{18}$

1. Weakening the independence of the Corruption Eradication Commission, the part that regulates the leadership is the highest responsibility is removed.

2. The supervisory board is more powerful than the head of the Corruption Eradication Commission.

3. The authority of the supervisory board includes technical handling of cases.

4. The standards for the prohibition of ethics and anti-conflict of interest for the supervisory board are lower than for the leadership and staff of the Corruption Eradication Commission.

5. The supervisory board may for the first time be elected from incumbent law enforcement officers with at least 15 years of experience.

6. The head of the Corruption Eradication Commission is no longer an investigator and public prosecutor so that he will be at risk of projustice actions in the implementation of prosecution duties.

7. One of the leaders of the Corruption Eradication Commission after this law was passed threatened that he could not be appointed because he was not old enough or less than 50 years old.

8. Trimming investigation authority.

9. Trimming wiretapping authority.

10. Hand-Catching Operation (OTT) becomes more difficult to carry out because it is more complicated to apply for wiretapping and other regulations in the Corruption Eradication Commission Law.

11. There is an article that risks being misinterpreted as if the Corruption Eradication Commission should not conduct Hand-Catching Operations (OTT) as it is today.

12. There is a risk of criminalization of Corruption Eradication Commission employees related to wiretapping due to unclear rules in the Corruption Eradication Commission Law.

13. There is a risk that civil servant investigators in the Corruption Eradication Commission are under the coordination and supervision of National Police investigators because Article 38 paragraph (2) of the Corruption Eradication Commission Law is deleted.

14. Reduced prosecution authority, in carrying out prosecutions the Corruption Eradication Commission must coordinate with related parties but it is not clear who the related parties are.

15. Corruption Eradication Commission employees are vulnerable to be controlled and are not independent in carrying out their duties because of their civil servant status.

16. There is uncertainty about the status of Corruption Eradication Commission employees whether they are Civil Servants or PPPKs (contract employees).

17. There is a risk within two years for investigators and investigators of the Corruption Eradication Commission who have been permanent employees.

18. Must become a Civil Servant without certainty about the transition mechanism to Civil Servant.

\footnotetext{
${ }^{18}$ Lihat dalam https://www.google.com/amp/s/amp.tirto.id/26-masalah-revisi-uu-kpk-jadi-tuntutan-demo-mahasiswa-jakarta-
} eiGl diakses tanggal 17 Desember 2019 
19. The term of SP3 for two years will make it difficult to handle corruption cases which are complex and transnational in nature.

20. Amendment of Article 46 paragraph (2) of the Law on the Eradication of Corruption Eradication Commission which has been the basis for specifically regulating the invalidity of provisions on special procedures that have made it difficult for law enforcers to process state officials.

21. There are conflicting norms.

22. Loss of advisory position to the Corruption Eradication Commission without clarity and transitional rules.

23. The loss of authority to handle cases that is troubling the public.

24. The Corruption Eradication Commission is only domiciled in the national capital.

25. There is no strengthening from the aspect of prevention.

26. The authority of the Corruption Eradication Commission to conduct supervision is reduced.

A number of civil society organizations have also issued objections to the Revision of the Corruption Eradication Commission Law, some of which are: ${ }^{19}$ :

1. The Center for Constitutional Studies (PUSaKO) Andalas University, PUSaKO sees the attitude of the DPR in trying to revise the Corruption Eradication Commission Law as full of problems and it is feared that it has the potential to weaken the Corruption Eradication Commission.

2. The Indonesian Judiciary Monitoring Society (MaPPI), Faculty of Law, University of Indonesia also urged the House of Representatives to postpone the revision of the Corruption Eradication Commission Law, actually increasing the workload of the DPR, which still has a lot of homework to complete the Prolegnas Bill, and others.

3. The Indonesian Legal Aid Foundation (YLBHI) sees that the DPR's action has fallen into the category of weakening the Corruption Eradication Commission. Weakening is not only through the Revision of the Corruption Eradication Commission Law in terms of handling cases such as investigations, wiretapping, to catch operations determined by the Corruption Eradication Commission Supervisory Board which is outside the Corruption Eradication Commission and looking for the leader of the Corruption Eradication Commission who weakens the eradication of corruption.

4. In accordance with the theory of legal certainty, amendments to the Corruption Eradication Commission Law are seen as inconsistent with the spirit of eradicating corruption that has become a reality in society. Moreover, with the existence of at least 26 problems that have been summarized by the Corruption Eradication Commission itself above, as well as many responses from various parties who reject the revision of the law. Although in fact there are pros and cons in responding to the revision of the Law.

Finally, sociologically, changes to the Corruption Eradication Law have violated the realities of life in society, because the Corruption Eradication Commission is still the sole icon of corruption eradication and is still an institution that is trusted by the public to carry out corruption eradication. As stated by the academic from Bandung below:

1. The Corruption Eradication Commission is trusted by the public. According to Moch. Zakaria, Dean of the Faculty of Social and Political Sciences at Al-Ghifari University, Bandung, stated that "The Corruption Eradication Commission emerged because of the

19 Lihat dalam https://www.google.com/amp/s/amp.tirto.id/masyarakat-sipil-ramai-ramai-tolak-revisi-uu-kpk-usulan-dprehCy diakses tanggal 06 Agustus 2020

${ }^{20}$ Lihat dalam https://www.google.com/amp/s/jabar.idntimes.com/news/jabar/amp/yogi-pasha/polemik-ruu-kpk-merupakanrespons-kepercayaan-masyarakat-kepada-lembaga-antirasuah diakses tanggal 06 Agustus 2020 
public distrust of other institutions such as the police and the prosecutor's office. When the Corruption Eradication Commission comes, people believe because they are able to catch corruptors".

2. The Community Responds, Moch. Zakaria said that "The public reaction regarding the revision of the Corruption Eradication Commission Law is a natural response, but it must be considered by related parties because our country is democratic".

3. Will continue to be trusted, Zakaria said, "I am sure the public will continue to believe in the Corruption Eradication Commission after the revision of the Corruption Eradication Commission Law is passed and what must be done now is the related parties starting from rebuilding trust from the community".

\section{F. Closing}

\section{a) Conclusion}

The philosophical, sociological and juridical basis for the formation and amendment of laws and regulations in the revision of the Corruption Eradication Commission Law have been fulfilled. First, the philosophical consideration is that the Corruption Eradication Commission's journey for 17 years has deviated from its original objective. Second, sociological considerations, public support for the Corruption Eradication Commission remains stable, although not at all levels of the bureaucracy and levels of society. Third, the juridical aspect, seen from the Constitutional Court (MK) decision regarding the judicial review of the Corruption Eradication Commission Law. In this decision, it was stated that the Corruption Eradication Commission was an independent branch of the executive power that deals with corruption issues. Juridically, it means that it is in accordance with the applicable legal rules and is made by the competent institution.

In the Revision of the Corruption Eradication Commission Law, seen from the perspective of a sociology of law or a sociology of legislation, that the fact of life of the Indonesian people still desperately needs a Corruption Eradication Commission, the Corruption Eradication Commission is still very trusted to eradicate corruption in Indonesia and does not want changes to the Corruption Eradication Commission Law. Such as changes that object to all of us that are listed in the Revision of the Corruption Eradication Commission Law, namely; weakening of the independence of the Corruption Eradication Commission, the existence of a Supervisory Board which is more powerful than the leadership of the Corruption Eradication Commission, cutting back investigations and wiretapping authority, making hand arrest operations more difficult, and etc.

\section{b) Advice}

a. Lawmakers must further strengthen the philosophical, sociological and juridical foundations in every law making and amendment.

b. Law makers must be able to involve sociologists, economists and other scientific experts in making and amending laws.

\section{Bibliography}

A. Book

Adji, Indriyanto Seno, dkk., 2016, Pengujian oleh Publik (Public Review) Terhadap Rancangan Undang-Undang Tentang Komisi Pemberantasan Tindak Pidana Korupsi, Jakarta, Indonesia Corruption Watch.

Bentham, Jeremy, 1979, Theory of Legislation. London, Trubner \& Co. 
Harahap, M. Yahya, 2002, Pembahasan Permasalahan Dan Penerapan KUHP Penyidikan dan Penuntutan, Jakarta, Sinar Grafika.

Hs, H. Salim, 2010, Perkembangan Teori Dalam Ilmu Hukum, Jakarta, PT. Rajagrafindo Persada.

Kansil, CST, Christine S.T Kansil, Engelien R, Palandeng dan Godlieb N Mamahit, 2009, Kamus Istilah Hukum, Jakarta, Jala Permata Aksara.

Mamudji, Sri, Hang Rahardjo, dkk., 2005, Metode Penelitian dan Penulisan Hukum, Jakarta, Badan Penerbit Fakultas Hukum Universitas Indonesia.

Marzuki, Peter Mahmud, 2008, Penelitian Hukum. Cet2. Jakarta: Kencana.

Muhammad, Abdul Kadir, 2004,Hukum dan Penelitian Hukum, Cet. 1, Bandung, PT. Citra Aditya Bakti.

R., Tomasic., "The Sociology Legislation", dalam Legislation and Society in Australia, The Law Foundation of New South Wales and George Allen and Unwin, Sidney, Australia, 1979.

Rahardjo, Satjipto dalam "Sosiologi Hukum; Perkembangan, Metode dan Pilihan Masalahnya" (editor Khudzaifah Dimyati), Surakarta, Universitas Muhammadiah Surakarta. 2002.

Rahardjo, Satjipto, 2006, Hukum Dalam Jagat Ketertiban, Jakarta, UKI Press.

Rizal, Jufrina, Sosiologi Perundang-Undangan dan Pemanfaatannya, Jurnal Hukum dan Pembangunan, Nomor 3 Tahun XXXIII.

Shidarta, 2006, Moralitas Profesi Hukum Suatu Tawaran Kerangka Berfikir, Bandung, PT. Revika Aditama.

Soekanto, Soerjono, 1990, Sosiologi Suatu Pengantar, Jakarta, PT. Raja Grafindo Persada.

Sriwidodo, Joko, 2020, Hukum Dalam Perspektif Sosiologi dan Politik di Indonesia, Yogyakarta, Kepel Press.

B. Internet

https://www.google.com/amp/s/amp.tirto.id/26-masalah-revisi-uu-Komisi Pemberantasan Korupsi-jadi-tuntutan-demo-mahasiswa-jakarta-eiGl diakses tanggal 17 Desember 2019

https://www.google.com/amp/s/amp.tirto.id/masy arakat-sipil-ramai-ramai-tolak-revisi-uu-Komisi Pemberantasan Korupsi-usulan-dpr-ehCy diakses tanggal 06 Agustus 2020

https://www.google.com/amp/s/jabar.idntimes.com/news/jabar/amp/yogi-pasha/polemik-ruu-

Komisi Pemberantasan Korupsi-merupakan-respons-kepercayaan-masyarakat-kepadalembaga-antirasuah diakses tanggal 06 Agustus 2020.

Setiawan, Adam, Balada KOMISI PEMBERANTASAN KORUPSI Dalam Perspektif Sosiologi Hukum, dalam https://www.google.com/amp/s/kastara.id/14/02/2019/balada-Komisi Pemberantasan Korupsi-dalam-perspektif-sosiologi-hukum/amp/ diakses tanggal 17 Desember 2019

Sunggono, Bambang, 1997, Metode Penelitian Hukum, Jakarta: PT. Raja Grafindo Persada. 064labib.blogspot.com diakses tanggal 17 Desember 2019. 